\title{
Who holds purse strings?
}

\section{London}

Ministers from countries that have ratified the 1987 Montreal Protocol are expected to agree this week to substantial reductions in the future use of chlorofluorocarbons (CFCs) and other ozonedepleting chemicals, at a London meeting to tighten the protocol. But convincing India, China and other developing countries to ratify the new protocol will be difficult if disagreements over finance to help these countries phase out CFCs are not resolved.

The United States decided earlier this month to support an international fund to help finance alternatives to CFCs in developing countries, reversing previous policy (see Nature 345, 193; 17 May 1990). UK Environment Secretary Chris Patten said that US action had removed a major obstacle to the success of the London meeting. But as government officials met last week to prepare an amended protocol for ministers to sign, it emerged that conditions on US participation in the fund were unacceptable to India and China.

If India and China both join the protocol, $\$ 240$ million may be needed before 1993. The fund is expected to be administered by the World Bank with advice from the United Nations Environment and Development Programme and policy determined by an executive body of 14 members, divided equally between developed and developing countries.

US delegates explained that the fund could not be an "open conduit", through which US money passes to developing countries. To ensure control over spending, the US should have a permanent seat on the executive body, and voting power should be weighted according to contributions to the fund, the delegates said. Assuming developed countries pay into the fund in proportion to their UN subscriptions, the United States will provide 25 per cent of the total.

Wang Yangzhu, who led the Chinese delegation to the preparatory meeting, said that China could not agree to the US conditions. "Every country must be equal" he said. An independent study has estimated that China will require $\$ 42.1$ million before 1993 to develop alternatives to CFCs.

Mahesh Prasad, head of the Indian delegation, also rejected the US position, and added that contributions to the fund should be linked to the (1986) figures on CFC emissions, in line with the 'polluter pays' principle. This would increase the US contribution to over 30 per cent of the total. Prasad also said that India was concerned that the establishment of an interim fund until 1993 might not be linked to a longer-term commitment. Developing countries are worried that they may be "lured" into ratifying the protocol and then find there is "no money after three years", he said.

The negotiations were closed to the press, but an authoratitive source expected the United States to back down on weighted voting in return for the assurance that decisions of the executive body must be reached by a large majority. China is expected to accept this solution, but India's position is less clear.

In comparison with the wrangles over financial management, there is broader agreement on the revised limits on future use of ozone-depleting chemicals suggested by Mostafa Tolba, executive director of the United Nations Environment Programme, with some countries pushing for even tighter limits. The Montreal Protocol currently demands that ratifying nations cut their CFC consumption by half before mid-1998, and freeze halon use at 1986 levels by 1992. Tolba's proposals call for CFCs and halons to be phased out by 2000 , and adds extra restrictions intended to phase out the use of carbon tetrachloride and halve the use of methyl chloroform by the end of the century. An annex to the protocol may also be drawn up, recommending that that hydrochlorofluorocarbons (HCFCs) are not used after 2040, at the latest. HCFCs will have an important role as transitional alternatives to CFCs, but also damage the ozone layer, albeit to a much smaller extent.

\section{PARIS MEETING}

\section{Global environment needs assessed}

\section{Paris}

HEADS of space agencies from the leading industrialized nations, as well as China, met Earth scientists and politicians in Paris last week to draw up plans for future cooperation over global environment monitoring. The meeting was proposed by France at last July's 'G7' summit in Paris, and the list of recommendations will be tabled in Houston next month when the G7 nations meet again.

The meeting was intended to identify issues that will enable planned and existing Earth observation programmes to provide the data that scientists will need in order to test international models of global environmental change. As Jacques-Louis Lions, of the French national space research centre (CNES) pointed out, the success of global monitoring depends on the continuity, precision and availability of space data. Priority will need to be given to the calibration of space instruments and questions of copyright and reciprocal exchange of data must be solved. In particular, developing countries must not be excluded.

Leonard Fisk, NASA associate administrator, calculated that the international Arctic ozone hole.
The extent of the ozone problem was revealed in a report from the UK government-sponsored Stratospheric Ozone Review Group, chaired by John Pyle from the University of Cambridge, published last week and circulated to delegates. Speaking at the opening of the London meeting, Patten said the report made "stark reading", documenting a long-term decline in winter ozone in the Northern Hemisphere and the potential for an

Peter Aldhous

- Anticipating a US phase out of HCFCs by 2015 , as suggested by proposals from the US Congress, DuPont announced last week that it has frozen plans for future HCFC production. Tony Vogelsberg, environmental manager of DuPont's Freon Products Division, in London for the Montreal Protocol conference, said that chemical companies cannot justify investment in HCFC plants unless allowed to produce HCFCs until about 2030.

Vogelsberg added that the Congress proposals could be "an environmental disaster": with production of HCFCs frozen in the US, developing countries may wait until newer alternatives become available, before moving from use of CFCs, which are many times more damaging to the ozone layer than HCFCs.

Dupont, the world's leading producer of CFCs, expects to have spent $\$ 240$ million restructuring its CFC business by the end of this year, part of a $\$ 1000$ million programme. Dupont now plans to switch production to hydrofluorocarbons (HFCs), which do not deplete stratospheric ozone. space programme for global environment monitoring will cost $\$ 30,000$ million over the next ten years. But, said Fisk, this is only about 0.01 per cent of total gross national products over the same period. NASA will provide an estimated $\$ 17,000$ million of this total, he said - about 10 per cent of the total amount the US government will spend on space exploration until 2000. Questioned about the realism of this commitment, given uncertainties in the recent past over Congress support for NASA, Fisk was confident. NASA now boasts one of the highest annual growth rates - about 15 per cent - of any of the US government agencies. "Given our present ignorance of the world and what we are doing to it, this is an effort we must make", said Fisk.

Meanwhile France, the most enthusiastic member of the European Space Agency (ESA), and keen to be seen as committed to environmental protection, has just reinforced Europe's presence in the 'Mission to Planet Earth' venture by promising to finance 23 per cent of the costs of ERS-2, ESA's next generation remote-sensing satellite.
Peter Coles 